\title{
AKTUELL STRAFFRÄTTSUTVECKLING INOM EU. HARMONISERING OCH ÖMSESIDIGT ERKÄNNANDE
}

AV PROFESSOR DAN FRÄNDE

This article looks at the latest developments in the criminal and procedural law within the EU. As a starting point, the author accepts the objective of harmonising the material criminal law, and concludes that much remains to be done. An EU-wide criminal code should be adopted to protect the financial interests of the European Communities and prevent serious cross-border crime. Much has been achieved in the field of mutual recognition. The biggest challenge will be the establishment of joint EU rules in respect to evidence in the sphere of criminal procedural law.

1. Mycket inom den EU-relaterade straff- och straffprocessrätten handlar i dag om harmonisering och ömsesidigt erkännande. Litteraturen är redan i det närmaste oöverskådlig. Jag skall här försöka mig på konststycket att säga något om EUstraffrätten med utgångspunkt i dessa fenomen.

Jag är ingen euroskeptiker, snarare tvärtom. Men jag sticker inte heller under stol med de problem som finns i dag, problem som hotar att försvåra eller till och med stoppa utvecklingen mot en övergripande (federal) straff- och straffprocessrätt inom EU i fråga om angrepp mot EU:s finansiella intressen samt i fråga om allvarlig gränsöverskridande brottslighet. Texten är i mångt och mycket en uppräkning av olika problem och svårigheter. En euroskeptiker ser givetvis saken annorlunda. För honom eller henne är problemen och svårigheterna närmast glädjeämnen som visar att ett sådant projekt är dömt att misslyckas.

Mellanstatliga och övernationella instrument som Eurojust, Europol och OLAF faller helt utanför framställningen. Frågan om en eventuell europeisk åklagare kommer dock att kort nämnas. Jag diskuterar inte heller problematiken kring valet mellan rambeslut och direktiv. Sökordet är här miljöbrott och det kända avgörandet C-176/03. Ett nytt avgörande är dock att vänta. Denna gång handlar det om ogiltigförklarandet av rådets rambeslut 2005/667/RIF av den 12 juli 2005 om förstärkning av det straffrättsliga regelverket för bekämpande av föroreningar orsakade av fartyg.

\footnotetext{
* Title in English: The Latest Developments in Criminal and Procedural Law within the EU. Harmonization and Mutural Recognition. Original in Swedish.
} 
2. Harmoniseringen av medlemsstaternas materiella straffrätt grundas på en utvidgande tolkning av artikel 31(e) i EU-fördraget och omfattar i dag ett förhållandevis brett område. ${ }^{1}$ Rambeslut har bl.a. getts om terrorism, penningförfalskning och barnpornografi. ${ }^{2}$ Hela den materiella straffrätten anses dock inte kunna vara föremål för harmoniseringsåtgärder.

För det första kan åtgärderna innehålla definitioner av straffrättsligt relevanta begrepp. Kända exempel utgörs här av terroristisk handling, människohandel etc. Det är även möjligt att inta krav på att olika typer av biståndshandlingar skall kriminaliseras. Åtminstone i Finland har dessa nya fenomen inte fallit under de normala reglerna om medverkan enligt SL 5 kap.. Definitioner av till brottsbegreppet hörande delar som t.ex. nödvärn, uppsåt eller förbudsvillfarelse är däremot uteslutna. EU kan inte heller påtvinga medlemsstaterna ett visst brottsbegrepp. ${ }^{3}$

För det andra kan harmoniseringen gälla straffhoten. Här är det fråga om det minimum som maximistraffet för ett visst brott måste ges i den nationella lagstiftningen. Det får också anses möjligt att ta in omständigheter som påverkar straffmätningen, medan det inte är tillåtet att föreskriva ett visst straff respektive ett visst minimistraff för ett bestämt brott. Inte heller synes det vara tillåtet att harmonisera straffsystemet så till vida att EU skulle ange vilka typer av sanktioner som måste finnas i varje medlemsland.

Man kan också tala om ett slags harmonisering av straffprocessrätten. Det är givetvis inte fråga om att samtliga medlemsländer skulle ta i bruk ett slags modellrättegångsbalk i brottmål. I stället handlar det om införandet av s.k. minimiregler. Rambeslutet om offrets ställning i straffprocessen från $2001^{4}$ är väl att betrakta som ett sådant. Som bekant har rambeslutet gett upphov till det s.k. Pupino-avgörandet från 2005. ${ }^{5}$ Så mycket längre har man inte kommit. Till dags dato föreligger ett förslag till rambeslut, dvs. förslaget till rambeslut om vissa processuella rättigheter i brottmål i Europeiska unionen från $2004 .{ }^{6}$ Därtill finns två grönböcker som anknyter till den misstänktes rättsställning. ${ }^{7}$ Det kan observeras att inget gjorts för att stärka den misstänktes möjligheter till juridiskt bistånd i gränsöverskridande processer. ${ }^{8}$

3. Det är ingalunda en självklarhet varför det behövs en harmonisering av den materiella straffrätten med hjälp av rambeslut. För gemenskapens del är det uppenbart att vissa gärningar står i direkt konflikt med gemenskapens målsättningar. Är det en gång gemenskapens uppgift att värna om miljön betyder nedsmutsning en direkt konflikt med detta mål. Men brott som människohandel, terrorism och narkotikasmuggling kan åtminstone inte anses direkt riktade mot gemenskapens intressen. Grunden för harmonisering inom unionen hittas i artikel 29 i EU-fördraget. Här anges att unionen är ett område som kännetecknas av frihet, säkerhet 
och rättvisa. I sig kunde man tänka sig att en hög brottslighet i en medlemsstat inte påverkar bedömningen av unionens säkerhetsnivå som en helhet. Men om brottsligheten är gränsöverskridande blir läget kanske ett annat.

Tanken bakom harmoniseringen grundar sig ytterst på preventiva hänsynstaganden. En viss gemensam standard på straffrätten behövs för att upprätta eller till och med förbättra säkerheten inom unionen. Om t.ex. en viss förberedande verksamhet för terroristiska anslag inte är kriminaliserad i en medlemsstat kan detta få vittgående följder i övriga medlemsstater.

Det är en i sig kontroversiell fråga om medlemsstaternas materiella straffrätt behöver harmoniseras eller inte. Låt oss anta att ett sådant behov existerar. Då måste man $\mathrm{i}$ ärlighetens namn säga att det som åstadkommits inte är särskilt imponerande. De brottsdefinitioner som skapats har knappast täppt till några större luckor i medlemsstaternas strafflagar. Minimigränsen för maximistraffet vill jag närmast beteckna som ett slags "Etikettenswindel". Det är ytterst sällan den övre delen av straffskalan används i praktiken.

För att uppnå en gemensam europeisk straffrättsstandard borde för det första straffrättens allmänna del förenhetligas. Här kan modell tas från Corpus Juris-förslaget. ${ }^{9}$ Vi behöver ett gemensamt brottsbegrepp, definitioner av klassiska brottselement som nödvärn, handlande på befallning, uppsåt, misstag, otillräknelighet etc. För det andra måste påföljdssystemet genomgå en radikal harmonisering. Detta omfattar inte bara minimistraff för vissa EU-relevanta brottskategorier utan även det konkreta bruket av enskilda straff. Slutmålet är således en EU-brottsbalk (för att nu uppmärksamma att Nordiska kriminalistmötet hålls i Stockholm). Ett sådant scenario är kanske för häftigt med tanke på den "normala" gränsöverskridande brottsligheten. Men man kunde kanske börja med de brott som riktar sig mot EU:s ekonomiska intressen.

I det s.k. Reform Treaty från sommaren 2007 anges - på samma sätt som i EU-grundlagen - att minimiregler kan antas när det gäller brottsdefinitioner och sanktioner. Prima facie verkar allt bli vid det gamla; någon formell öppning mot en EU-brottsbalk kan inte skönjas. Men EU-rätten är dynamisk och i något skede kan det visa sig att samhällsutvecklingen kräver en mera omfattande harmonisering.

På något sätt tycks harmoniseringen av straffprocessrätten, åtminstone i form av minimiregler kring parternas processuella ställning, vara lättare att koppla till ett entydigt behov. Ur unionens synvinkel ser man stärkandet av individens rättsliga ställning inte bara som ett värde i sig utan kanske i första hand som ett medel för att underlätta genomförandet och konkretiseringen av principen om ömsesidigt erkännande. Detta sker enligt kommissionens uppfattning dock inte direkt utan så att den gemensamma tilliten till varandras rättsordningar förstärks. ${ }^{10}$ Här finns det inget att anmärka under förutsättning att man accepterar principen om ömsesidigt erkännande. 
5. Principen om ömsesidighet är sedan Tammerfors-toppmötet 1999 en hörnsten i det straffrättsliga samarbetet. Detta är i sig inget att förvåna sig över. Ett effektivt och avskräckande straffrättssystem förutsätter även att begångna brott lagförs och att de utdömda straffen verkställs. Är gränserna öppna och rörligheten maximerad måste det straffrättsliga samarbetet mellan staterna uppvisa samma flexibilitet och snabbhet. Det är egentligen förvånande att ömsesidigt erkännande anammades så pass sent inom straffprocessrätten.

Principens grundidé är som känt mycket enkel. Domar och beslut som har fattats i en medlemsstat skall erkännas och verkställas i de övriga medlemsstaterna utan några extra villkor eller hinder. Följande godkända rambeslut förverkligar principen:

- rambeslutet om en europeisk arresteringsorder och överlämnande mellan medlemsstaterna ${ }^{11}$,

- rambeslutet om verkställighet i Europeiska unionen av beslut om frysning av egendom eller bevismaterial ${ }^{12}$,

- rambeslutet om tillämpning av principen om ömsesidigt erkännande på bötesstraff ${ }^{13}$ och

- rambeslutet om tillämpning av principen om ömsesidigt erkännande på beslut om förverkande..$^{14}$

Ytterligare har ett slags politisk överenskommelse träffats kring förslaget till rambeslut om ett europeiskt bevisupptagningsbeslut avseende föremål, handlingar eller uppgifter som skall företas i brottmå $1^{15}$ samt kring förslaget till rambeslut om ett europeiskt verkställighetsbeslut och överförande av dömda personer mellan Europeiska unionens medlemsstater. ${ }^{16}$

Vi ser att samtliga rambeslut handlar om åtgärder till den tilltalades nackdel. Ur individens synvinkel har principen även en positiv sida. ${ }^{17}$ En dom i en medlemsstat skall erkännas så att samma gärning inte kan bli föremål för ny prövning i en annan medlemsstat. Något sådant rambeslut existerar inte i dag men samma resultat uppnås genom artikel 54 i Schengenavtalet. Likaså är det konsekvent att vid straffmätningen $i$ enlighet med nationella regler beakta att gärningsmannen har dömts för brott utomlands. För att detta skall fungera i praktiken krävs ett systematiskt utbyte av straffregisteruppgifter. Kring förslaget till rambeslut om utbyte av straffregisteruppgifter från 2005 har politiskt samförstånd nåtts 13.6.2007. ${ }^{18}$

De senaste årens diskussion kring ömsesidigt erkännande har i hög grad dominerats av arresteringsordern. Transformationen till gällande rätt har varit mödosam med upphävandet av den tyska lagen som ett slags spektakulär höjdpunkt. Den 
tyska lagen från 2006 gäller enligt vad jag vet fortfarande. I avgörandet C-303/05 tog EG-domstolen ställning till rambeslutets laglighetsgrund och konstaterade att det inte fanns något att anmärka.

Också det nordiska utlämningssamarbetet har påverkats av rambeslutet om en europeisk arresteringsorder. Eftersom de nordiska EU-medlemmarna Danmark, Finland och Sverige var bundna av rambeslutet deklarerade de nordiska justitieministrarna redan under ett möte på Svalbard i juni 2002 att den nordiska utlämningslagen måste anpassas till den nya ordningen. Så har även skett 15.12.2005 genom undertecknandet av konventionen om överlämnande mellan de nordiska staterna på grund av brott (Nordisk arresteringsorder). Danmark har hunnit längst med ikraftsättandet av konventionen. Genom en lagändring 30.4.2007 har konventionen transformerats till den danska lagen om utlämning. I Finland har en regeringsproposition om saken överlämnats till riksdagen hösten 2007. ${ }^{19}$

I förhållande till rambeslutet om den europeiska arresteringsordern går konventionen klart längre $\mathrm{i}$ och med att den avskaffar samtliga krav på dubbel straffbarhet, också gällande egna medborgare. Det enda undantaget utgörs här av Island.

6. Man kan orda mycket om principen om ömsesidigt erkännande. För att undvika förhastade slutsatser är det skäl att redan nu påpeka att det godkända rambeslutet inte innebär något fullständigt erkännande av utomlands givna domar och beslut. I samtliga rambeslut ingår olika typer av vägransgrunder och åtminstone i Finland har man i samband med transformationen tagit in vissa nya grunder.

Här tar jag upp endast två aspekter på principen. Den första gäller betydelsen (eller betydelselösheten) av den omständigheten att det handlar om en princip. Den andra aspekten eller frågeställningen är kopplad till användningen av principen på transport av bevis från en rättsordning till en annan.

7. Som bekant kan begreppet "princip" normteoretiskt förstås på olika sätt. ${ }^{20} \mathrm{Nå}-$ gon konsensus kan man inte gärna tala om. Ser man till hur principen har "tilllämpats" i de godkända rambesluten ligger det nära till hands att uppfatta principen som ett optimeringspåbud. I det konkreta rambeslutet har principen starkt påverkat det faktiska innehållet men även andra hänsynstaganden har beaktats. Så får t.ex. vägransgrunden ne bis in idem ses som ett beaktande av kraven på en rättvis rättegång. Som en vägransgrund hänför sig bristande straffmyndighet i sin tur till ett lands fundamentala straffrättsuppfattning. I rambeslutet om ett europeiskt bevisupptagningsbeslut har för Tysklands del överenskommits om att vissa brott på 32-listan faller bort. ${ }^{21}$ Här har uppenbarligen Tyskland ansett att det grundrättsförankrade kravet på bestämd lagstiftning hindrar bruket av vissa generalklausulaktiga brottsbenämningar på listan. 
Däremot kan de enskilda normerna i ett på ömsesidigt erkännande grundat rambeslut inte uppfattas som en samling principer som i samband med den nationella transformeringen fritt kunde avvägas mot andra principer. Bestämmelserna i ett visst rambeslut är regler som skall följas. De enskilda nationalstaternas "egna" lösningar uppfattar jag som explicita regelundantag som låter sig göras tack vare bristen på effektiva sanktioner mot avvikelser. Den verkligt intressanta frågan gäller sedan tolkningen av de inhemska regler genom vilka rambeslutet har transformerats till gällande rätt. Efter Pupino-avgörandet är vi väl medvetna om att rambeslutet i sig har en betydande tolkningsverkan beträffande nationella regler. Men kan vi också säga att principen om ömsesidigt erkännande alltid fungerar som ett tolkningsargument till förmån för den utfärdande staten? Åtminstone beträffande den europeiska arresteringsordern konstateras i artikel 1(2) att varje arresteringsorder skall verkställas $i$ enlighet med principen om ömsesidigt erkännande samt bestämmelserna i detta rambeslut. Svaret på frågan kan få betydande praktiska konsekvenser eftersom de nationella rambeslutstransformeringarna ofta tillkommer snabbt och utan en grundlig beredning. Personligen är jag inte beredd att ge principen denna funktion i de nationella rättsordningarna. Men helt betydelselös är den knappast.

8. Mycket tyder på att frågan om bevisens fria rörlighet mellan medlemsländerna kommer att utgöra en verklig stötesten för tillämpningen av principen om ömsesidigt erkännande. I förslaget till rambeslut om ett europeiskt bevisupptagningsbeslut anger kommissionen som sitt syfte att komma med en mera allmän modell för behandling av bevis i en europeisk kontext. I den senaste aktionsplanen konstateras att kommissionen avser att publicera en grönbok i ämnet under hösten 2007.

Bevisen är så till vida svårgreppade ur principens synvinkel eftersom varje land har en rad processuella bestämmelser om hur bevis får upptas och hur de skall presenteras i rätten. Följande exempel från finsk rätt kan nämnas. Under vissa villkor kan en upptagning av en minderårig målsägandes berättelse användas som bevis i den finska huvudförhandlingen. En upptagning har gjorts utomlands i enlighet med där gällande regler som inte tillåter att den misstänktes ombud medverkar vid förhöret. En sådan upptagning strider mot de finska reglerna och frågan uppstår om den finska domstolen skall acceptera den utländska upptagningen som ett giltigt bevis i rättegången? Frågan är kontroversiell och skall inte lösas här. Men den antyder problematiken. I förslaget till rambeslut om ett europeiskt bevisupptagningsbeslut ingår två försök att åtminstone minimera riskerna för konflikter mellan rättsordningar. För det första får det utfärdande landet inte besluta om en sådan bevisupptagning som inte vore möjlig i det egna landet. För det andra skall det verkställande landet iaktta sådana formaliteter som det utfärdande landet begär under förutsättning att detta inte strider mot grunderna för den verkställande statens rättsordning (artikel 13). 
Det problemkomplex som lösningen inte lyckas tackla hör samman med den äkta gränsöverskridande brottsligheten, dvs. den där förundersökningsåtgärder har genomförts i flera länder. Alla medverkande kan kanske inte åtalas i samma rättegång och det land som drivit processen har därefter inget intresse av att begära att någon eller några gärningsmän överlämnas. Det kan också vara så att dessa "överblivna" gärningsmän i huvudsak utfört sina gärningar i något visst land där territorialiteten utgör en obligatorisk vägransgrund. Kan de bevis som samlats i huvudmålet och som även talar mot gärningsmännen återanvändas i den nya rättegången, fastän de tillkommit på ett sätt som inte godtas i det aktuella rättegångslandet? Ifall en europeisk åklagare blir verklighet $i$ enlighet med ändringsfördraget och ifall planerna på regler om lösandet av kompetenskonflikterna mellan medlemsstaterna genomförs ökar sannolikheten för att resultatet av flera förundersökningar koncentreras till ett visst land. Mycket tyder på att principen om ömsesidigt erkännande inte som sådan kan tillämpas på dylika bevisöverföringar. ${ }^{22}$ Här förutsätts nog någon form av gemensam standard, vilket pekar mot en europeisk rättegångsbalk i brottmål. Personligen bedömer jag att detta är betydligt mera realistiskt än en gemensam brottsbalk.

\section{Noter:}

Det är givetvis möjligt att med hjälp av stipulativa definitioner skilja mellan tillnärmning och harmonisering. Eftersom harmonisering verkar vara det begrepp som används mest ger jag mig inte i kast med saken. Se t.ex. Bernd Hecker: Europäisches Strafrecht. 2 Auflage 2007, s. 397-443 och Steve Peers: EU Justice and Home Affairs Law. Second Edition 2006, s. 402-410.

3 Om olika länders brottsbegrepp, se Kai Ambos: 100 Jahre Belings "Lehre vom Verbrechen": Renaissance des kausalen Verbrechensbegriffs auf internationaler Ebene? ZIS 10/2006 (http:// www.zis-online.com) s. 464-471. EGT 2001 L 82/1.

C-105/03. $\operatorname{KOM}(2004) 328$ slutlig. $\operatorname{KOM}(2005) 696$ slutlig om ne bis in idem-kravet och $\mathrm{KOM}(2006) 174$ slutlig om oskuldspresumtionen. Om detta, se t.ex. Dan Frände: Om rättsligt försvar i EU. I "Josefs resa. Vänbok till Josef Zila". Uppsala 2007 s. 71-84.

$9 \quad$ Se Nils Jareborgs översättning av förslaget till svenska. Uppsala 1997.

$10 \quad$ Se t.ex. $\operatorname{KOM}(2005) 195$ slutlig.

$11 \quad$ EGT 2002 L 190/1.

12 EUT 2003 L 196/45.

13 EUT 2005 L 76/16.

14 EUT 2006 L 328/59.

$15 \operatorname{KOM(2003)} 688$ slutlig. Rådet ingick överenskommelsen 1-2.6.2006.

16 EUT 2005 C 150/1. Råder ingick överenskommelsen 15.2.2007. 
17 Se t.ex. Petter Asp: Ömsesidigt erkännande av europeiska domar och beslut i straffprocessen - erfarenheter och tillämpningsfrågor. Forhandlingerne ved Det 37. nordiske Juristmøde i Reykjavik 18.-20.august 2005. Bind I. Reykjavik 2005 s. 57-80.

$18 \operatorname{KOM}(2005) 690$ slutlig.

19 RP 51/2007 rd.

20 Läs gärna Nils Jareborg: "Vad är en princip?" Hittas bl.a. i "Inkast i straffområdet”. Uppsala 2006 s. 159-167.

${ }_{21}$ Om detta rambeslut ur en finsk synvinkel, se Dan Frände: Om bevisupptagning inom EU. “Oikeudenkäyntejä ja tuomioistuimia. Juhlakirja Juha Lappalainen 60 vuotta." Helsinki 2007 s. 69-84.

22 Frågor i anslutning till detta har utförligt behandlats av Sabine Gleß: Beweisrechtsgrundsätze einer grenzüberschreitenden Strafverfolgung. Baden-Baden 2006.

Adress:

Institutionen för straff- och processrätt

Helsingfors universitet

Postbox 4

FIN - 00014 Helsingfors 